\title{
The Correlation Between Preeclampsia and the Incidence of Low Birth Weight (LBW) in RSU PKU Muhammadiyah Bantul
}

\author{
Nur'aisyah $^{1}$, Sholaikhah Sulistyoningtyas ${ }^{2, *}$ \\ ${ }^{1,2}$ Aisyiyah University, West Ringroad 63 Nogotirto Gamping Sleman 55292, Yogyakarta, Indonesia \\ ${ }^{2}$ Sholaikhahtyas@unisayogya.ac.id* \\ * corresponding author \\ Submission date: 10 Juli 2020, Receipt date: 15 Juli 2020, Publication date: 1 November 2020
}

\begin{abstract}
MMR and IMR in the world as well as in Indonesia are still a serious problem because this figure is an indicator of national health. The common cause of infant and neonatal mortality in Bantul Regency is low birth weight $(L B W)$. One of the factors causing $L B W$ is maternal disease factors that are directly related to pregnancy. One of them is preeclampsia. The purpose of this study was to determine the Correlation between Preeclampsia and the Incidence of Low Birth Weight Infants (LBW) at PKU Muhammadiyah Bantul Hospital in 2019. The design of this study used the correlation analytical method with a case control approach. The sampling method in this study used total sampling technique with the total sample size of the study were 174 newborns. The data collection technique used secondary data by collecting baby medical record data and maternal medical record data. The analysis technique used the chi square test. Babies who experienced $L B W$ were as many as 87 (50\%), did not experience $L B W$ as many as $87(50 \%)$, those who had preeclampsia were 45 (25.9\%), did not experience preeclampsia as many as 129 (74.1\%). The results of the study based on the chi square test showed that there was no correlation between preeclampsia and the incidence of low birth weight $(L B W)$ with $p=0.863$ and an odds ratio of 0.942. The conclusion is that there is no correlation between preeclampsia and the incidence of low birth weight babies $(L B W)$, the $p$ value is $0.863>0.05$. It is suggested that further analysis of other maternal factors on the incidence of low birth weight in PKU Muhammadiyah Bantul Hospital.
\end{abstract}

Keywords: $L B W$, preeclampsia

\section{INTRODUCTION}

Infant and maternal mortality rates in the world as well as in Indonesia are still a serious problem because this figure is an indicator of national health. According to WHO (World Health Organization), the infant mortality rate in 2015 reached $75 \%$ of all underfive deaths. The highest risk of a child dying before completing the first year of age in Africa is around 55 per 1,000 live births, which is five times higher than Europe which is only about 10 per 1,000 live births (WHO, 2015) in Low Birth Weight Babies (LBW) there is a lot of risk of problems in the body system, due to an unstable body condition. Perinatal mortality in LBW infants is 8 times greater than normal infants. The prognosis is worse if the lower the body weight, death is often due to neonatal complications such as asphyxia, aspiration, pneumonia, intracranial hemorrhage, hypoglycemia. If life will 
be found nerve damage speech disorder, low intelligence level. (Proverawati \& Ismawati, 2017)

In 2015, through data from the Indonesian Demographic Health Survey (IDHS), the Infant Mortality Rate (IMR) was 22.23 per 1000 live births. Whereas in the Special Region of Yogyakarta, cases of infant mortality fluctuated from 2014 - 2017. In 2014 it was 405 and decreased quite a lot in 2015, namely to 329 , decreased to 278 in 2016, but again rose to 313 in 2017. The highest infant mortality was in Bantul Regency (108 cases) $34.50 \%$ and the lowest was in Yogyakarta City (33 cases) 10.54\%. The common causes of infant and neonatal mortality in Bantul Regency are $20.37 \%$ low birth weight (LBW) and $18.51 \%$ congenital abnormalities. In addition, other causes of infant mortality that are often encountered in the Special Region of Yogyakarta include asphyxia at birth due to a long time in the birth canal, transverse location, as well as a narrow pelvis. (DIY health profile, 2017).

Certain factors are known to be the cause of LBW including maternal factors, fetal factors, and placental factors. One of the factors causing LBW is maternal disease. Diseases that are directly related to pregnancy, such as preeclampsia / eclampsia, hyperemesis gravidarum, antepartum bleeding and infections during pregnancy (bladder and kidney infections) (Proverawati, 2010).

The role of midwives in reducing the incidence of LBW and preeclampsia is expected that midwives can optimize health services before pregnancy, pregnancy, childbirth, and the period after delivery (Minister of Health Regulation, No. 97/2014 CHAPTER II articles 5-6). Optimizing the quality of children's growth and development from the time they are in the womb to training mothers to provide basic needs of infants' growth and development perinatally and by optimizing the integrated ANC services so that the incidence of LBW and preeclampsia in Indonesia and in developed and developing countries can be resolved immediately. Therefore, midwives need to constantly improve their competence, one of which is by increasing the understanding of midwifery care from pregnant women to childbirth and midwifery care for infant health (Septiani, 2015).

A preliminary study conducted in December at PKU Muhammadiyah Bantul Hospital in 2019 obtained from medical record data and labor registers, the number of patients with LBW babies from January to December 2019 was 87 babies with 1116 newborns. From the results of preliminary studies and previous research, researchers are interested in conducting research "The Correlation between Preeclampsia and the Incidence of Low Birth Weight Infants (LBW) at PKU Muhammadiyah Bantul Hospital in 2019.

\section{RESEARCH METHODS}

The research method used correlation analysis with a case control approach. The sample in this study were 174 newborns. The research sample was obtained using nonprobability techniques with total sampling technique. The analysis used was the Chi Square bivariate analysis. 


\section{RESULTS AND DISCUSSION}

Table 1. The Distribution of LBW Frequency in PKU Muhammadiyah Bantul Hospital in 2019

\begin{tabular}{lcc}
\hline \multicolumn{1}{c}{ Characteristics } & Frequency & $(\boldsymbol{\%})$ \\
\hline LBW & 87 & 50 \\
Not LBW & 87 & 50 \\
Total & 174 & 100 \\
\hline
\end{tabular}

Secondary data 2019

Based on table 4.1, it shows that the number of respondents in this study were 174 respondents $(100 \%)$ with the criteria of $87(50 \%)$ as a case sample in infants who experienced LBW and 87 respondents $(50 \%)$ as a control sample in infants who did not experience LBW.

Table 2. Distribution of Preeclampsia Frequency in PKU Muhammadiyah Bantul Hospital in 2019

\begin{tabular}{lcc}
\hline \multicolumn{1}{c}{ Characteristics } & Frequency & $(\boldsymbol{\%})$ \\
\hline Preeclampsia & 45 & 25.9 \\
Not preeclampsia & 129 & 74.1 \\
Total & 174 & 100 \\
\hline
\end{tabular}

Secondary data 2019

Based on table 4.2, it can be seen that the majority of maternal characteristics do not experience preeclampsia as many as 129 people $(74.1 \%)$ and those who experience preeclampsia are 45 respondents $(25.9 \%)$ out of 174 respondents.

Table 3. Frequency Distribution of the Correlation between Preeclampsia and the Incidence of Low Birth Weight Infants (LBW) at PKU Muhammadiyah Bantul Hospital in 2019

\begin{tabular}{|c|c|c|c|c|c|c|c|c|}
\hline \multirow{3}{*}{ Preeclampsia } & \multicolumn{8}{|c|}{ LBW Incidence in Newborns } \\
\hline & \multicolumn{2}{|c|}{ LBW } & \multicolumn{2}{|c|}{ Not LBW } & \multicolumn{2}{|c|}{ Total } & \multirow[t]{2}{*}{ p-value } & \multirow[t]{2}{*}{ OR } \\
\hline & $\mathbf{F}$ & $\%$ & $\mathbf{F}$ & $\%$ & $\mathbf{F}$ & $\%$ & & \\
\hline preeclampsia & 22 & 48.9 & 23 & 51.1 & 45 & 100 & \multirow{3}{*}{0.863} & \multirow{3}{*}{0.942} \\
\hline Not preeclampsia & 65 & 50.4 & 64 & 49.6 & 129 & 100 & & \\
\hline Total & 87 & 50 & 87 & 50 & 174 & 100 & & \\
\hline
\end{tabular}

Secondary data 2019

Based on table 4.3 above, it shows that respondents who experienced the most incidence of LBW were mothers who did not experience preeclampsia as many as 65 people $(50.4 \%)$ and mothers who experienced preeclampsia were 22 people $(48.9 \%)$ of the total respondents who experienced LBW incidence as many as 87 people $(50 \%)$. The results of the calculation of spss with the chi square test obtained a p value of 0.863 (p> 0.05 ). The results showed that there was no correlation between preeclampsia and the incidence of low birth weight babies (LBW) at PKU Muhammadiyah Bantul Hospital.

Based on table 4.3 above, it shows that respondents who experienced the most incidence of LBW were mothers who did not experience preeclampsia as many as 65 people $(50.4 \%)$ and mothers who experienced preeclampsia were 22 people $(48.9 \%)$ of the number of respondents who experienced LBW incidence as many as 87 people $(100 \%)$.

The results of the bivariate analysis conducted to test the correlation between preeclampsia and LBW using the chi square test obtained $\mathrm{p}$ value $=0.863 \alpha=0.05$, then $\mathrm{p}>\alpha$, so that Ho is accepted and Ha is rejected, meaning that there is no correlation 
between preeclampsia and the incidence of low birth weight babies (LBW) at PKU Muhammadiyah Bantul Hospital.

The results of this study are in line with previous research conducted by Lestari, in Banjarmasin in 2015 the results showed that preeclampsia was not related to the incidence of LBW $(p=0.539)$ with a correlation coefficient of 0.045 . This study assumes that there were other more dominant factors of the incidence of LBW, namely the lack of ANC services quality, economic and cultural factors play a major role in the incidence of LBW, because the family economy can show a picture of the family's ability to meet the nutritional needs of mothers during pregnancy which plays a role in fetal growth.

This research is in contrast to Ni Hartati's research in Denpasar in 2018 showing a correlation between preeclampsia and LBW of 4.752, which means that preeclampsia mothers are four times more likely to have babies with low birth weight (LBW) and Bertin Mallisa's research in hammer years (2011-2012) There is a correlation between preeclampsia and the incidence of low birth weight babies with a value of $p=0.003$ and a weak correlation strength of 0.215 . In this study, preeclampsia was also found to be a risk factor 2.48 times greater the cause of LBW than non-preeclampsia.

Research conducted by Lisnawati in Palu in 2019 the results of the chi square test p-value $=0.197(0.197>0.05)$, the results showed that although the prevalence of LBW was high in mothers with preeclampsia, there was no significant effect between preeclampsia and the incidence of low birth weight infants. The assumption of the researchers stated that mothers who did not experience preeclampsia generally gave birth to babies who were not LBW but there were still mothers with preeclampsia who gave birth to LBW babies due to other factors, namely gestational age because babies born with gestational age were not yet full-term (term) still going through the process of growth and fetal organs are not complete yet, so the baby will be LBW, and also because of family economic factors. Inadequate biological, social, economic, environmental and lifestyle factors, either before or during pregnancy, can cause low birth weight. Families who are able to meet the nutritional needs of pregnant women will prevent the incidence of mothers giving birth to LBW babies.

According to Proverawati \& Ismawati (2017) factors that can cause LBW are maternal factors including maternal complications during pregnancy such as preeclampsia, anemia, hypertension, HIV AIDS, multiple pregnancies, birth spacing too close and having a previous history of LBW, socioeconomic conditions, mother smokers and others. Fetal factors include chromosomal abnormalities, chronic fetal infection, familial dysautonomia, radiation, multiple pregnancy, and pancreatic aplasia. Placental factors include reduced surface area, infarction, detached placental tumors and others. environmental factors include living in highlands, exposed to radiation and exposure to toxic substances.

The high incidence of LBW is a problem that must be resolved because if it is not treated seriously LBW can cause diseases including asphyxia, aspiration, pneumonia, intracranial bleeding, and hypoglycemia. If you live, you will find nerve damage, speech disorders, low levels of intelligence. (Proverawati \& Ismawati, 2017) Preeclampsia is a syndrome in pregnancy ( $>20$ weeks), hypertension $(\geq 140 / 90 \mathrm{mmHg})$ and proteinuria ( $>0.3 \mathrm{~g} /$ day). Occurs in $2-5 \%$ of pregnancies and the maternal mortality rate is $12-15 \%$. (Malha et al, 2018). Pregnant women with preeclampsia experience decreased utero placental perfusion, hypovolemia, vasospasm, and damage to the endothelial cells of the placental blood vessels. Abnormalities of placental blood vessels in preeclampsia / eclampsia mothers can cause chronic hypoxia and impaired fetal nutrition so that fetal 
growth retardation often occurs which can lead to low birth weight (LBW). (Lestari et al, 2015).

Until now the cause of preeclampsia has not been known, but there are those who claim that preeclampsia can occur in certain groups, including mothers who have internal factors such as age, because increasing age is also more susceptible to increased chronic hypertension and faces a greater risk of suffering hypertension due to pregnancy, history of childbirth, heredity, history of pregnancy, history of preeclampsia. (Situmorang et al, 2016).

The incidence of preeclampsia in PKU Muhammadiyah Bantul Hospital is quite low, this is because preeclampsia can be prevented by regular and quality pregnancy examinations. Quality antenatal care with established service standards can detect complications in pregnancy, including detection of preeclampsia. The goals of antenatal care are for early detection of any increase in blood pressure during pregnancy, screening for preeclampsia, and taking appropriate action in preparation for referral. Prual, et.all, 2012 research in Nigeria stated that the quality of risk factor examination during antenatal consultation has an effectiveness in preventing and predicting obstetric complications. (Fatkhiyah et al, 2016).

The results of this study are not in line with the theory that pregnant women with preeclampsia experience decreased utero placental perfusion, hypovolemia, vasospasm and damage to placental blood vessel endothelial cells. Abnormalities of placental blood vessels in mothers with preeclampsia / eclampsia can cause chronic hypoxia and impaired fetal nutrition so that fetal growth retardation often occurs which can lead to low birth weight (LBW). (Lestari et al, 2015).

Seeing this situation gives a reminder that there are other factors that are more dominant in the incidence of LBW, such as antenatal care. Antenatal services are services provided to mothers during pregnancy with a minimum of 4 antenatal visits. The incidence of LBW is related to a lack of quality antenatal care. Mothers who receive early and continuous and complete health services will have better pregnancy outcomes than mothers who do not receive them. Mothers who do not receive antenatal care have a possible risk of giving birth to LBW compared to mothers who receive antenatal care (Lestari et al, 2015). Other factors that influence the incidence of LBW, namely economy and culture are very important in the incidence of LBW, because the family economy can show a picture of the family's ability to meet the nutritional needs of mothers during pregnancy which plays a role in fetal growth. Socio-economic conditions play a very important role in the emergence of LBW. The highest incidence is in the low socioeconomic group, this is due to poor nutrition and lack of pregnancy checks. Meanwhile culture plays a very important role because culture still adhere to the belief that there is still dietary abstinence, so the mother's nutrition is not sufficient. (Lestari et al, 2015).

\section{CONCLUSION}

The frequency distribution of LBW incidents at PKU Muhammadiyah Bantul Hospital in 2019 was as many as 87 babies. The frequency distribution of the incidence of preeclampsia at PKU Muhammadiyah Bantul Hospital in 2019 was 45 people. There is no correlation between preeclampsia and the incidence of low birth weight babies $(\mathrm{LBW})$, the $\mathrm{p}$ value is $0.863>0.05$. 


\section{REFERENCES}

Dinas Kesehatan Bantul. (2018). Profil Kesehatan Kabupaten Bantul. Dinas Kesehatan Bantul.

Fatkhiyah Natiqotul, Kodijah dan Masturoh (2016). Determinan Maternal Kejadian Preeklamsia. Jurnal keperawatan soedirman. 11 (1)

Hartati, N.Y. Surinati I.D.A.K and Pradnyaningrum. N.N.D.V (2018). Preeklamsia dengan Berat Badan Lahir Rendah (BBLR) Pada Ibu Bersalin. Jurnal Gema Keperawatan. 11 (1)

Lestari Reny Diah, Ika Mardiatul Ulva dan Siti Maryam (2015). Hubungan umur, paritas dan preeklamsia dengan kejadian berat badan lahir rendah di RSUD

Lisnawati et al. (2019). Preeklamsia dan bayi berat lahir rendah (BBLR) di RSU anutapura palu. Jurnal ilmu kesehatan , 42-47.

Profil kesehatan DIY. (2017). Profil Kesehatan DIY. yogyakarta.

Proverawati dan Ismawati. (2017). BBLR Berat Badan Lahir Rendah. Yogyakarta: nuha medika.

Proverawati, Atikah. (2010). Berat Badan Lahir Rendah . Yogyakarta: nuha medika. SDKI . (2017). Angka Kematian Neonatal. BKKBN.

Septiani, R. (2015). Upaya Gerakan Sayang Ibu (GSI) Save Motherhood. Journal Kesehatan, 2 (2)

Situmorang Tugor H, Yuhana Damantalm, Afrina Januarista dan Sukri (2016). Faktorfaktor yang berhubungan dengan kejadian preeklamsia pada ibu hamil di poli KIA RSU Anutapura palu. Jurnal kesehatan tadulako, 2 (1) 1-75.

WHO. (2015). World Health Statistics 2016 Monitoring Health For The SDGS. france: WHO. 